\title{
The effects of using seed treatments on sprouting, health condition and yield of potato
}

\section{Wpływ zaprawiania bulw na wschody, zdrowotność i plonowanie ziemniaka}

\author{
Ewa Moszczyńska ${ }^{1}{ }^{*}$, Maria Pytlarz-Kozicka², Jakub Grzeszczuk ${ }^{1}$
}

\section{Summary}

The impact of applying Prestige 290 FS, as well as biological treatments: FZB 24 WG and Proradix WP on the infection of potato tubers by Rhizoctonia solani and Streptomyces scabiei, the sprout development rate and the yield of potato tubers of three cultivars (Cyprian, Finezja and Flaming) was studied in the years 2011-2013. The experiment was conducted in a randomized split-block method in 4 repetitions. The applied chemical treatment significantly increased the potato sprouting rate and decreased the percentage of tubers infected by $R$. solani when compared to the application of biological treatments, as well as not treated tubers. The treatment did not affect the infection rate of tubers caused by $S$. scabiei. The infection of tubers caused by $R$. solani did not depend on the cultivar, while in case of $S$. scabiei the highest infection rate was observable in case of the Cyprian cultivar. Applying both chemical and biological treatments did not affect the yield of tubers.

Key words: sprout; seed treatment; crop health; yield; potato

\section{Streszczenie}

W latach 2011-2013 badano wpływ zaprawy chemicznej Prestige 290 FS oraz zapraw biologicznych: FZB 24 WG i Proradix WP na porażenie bulw przez Rhizoctonia solani i Streptomyces scabiei, wielkość wschodów oraz plonowanie bulw trzech odmian ziemniaków (Cyprian, Finezja i Flaming). Doświadczenie polowe zostało przeprowadzone w Pawłowicach, metodą split-plot, w czterech powtórzeniach. Zastosowanie zaprawy chemicznej wpłynęło istotnie na wyższe wschody oraz niższy procent bulw porażonych przez $R$. solani w porównaniu do zapraw biologicznych oraz bulw niezaprawionych. Zastosowane zaprawy nie wpłynęły różnicująco na porażenie bulw przez S. scabiei. Porażenie bulw przez $R$. solani nie zależało od zastosowanych odmian. Natomiast największy procent bulw porażonych przez S. scabiei stwierdzono u odmiany Cyprian. Zastosowanie zaprawy chemicznej i zapraw biologicznych nie wpłynęło istotnie na wielkość plonu bulw ziemniaka.

Słowa kluczowe: wschody; zaprawy; zdrowotność roślin; plon; ziemniak

\footnotetext{
Uniwersytet Przyrodniczy we Wrocławiu Wydział Przyrodniczo-Technologiczny Plac Grunwaldzki 24A, 50-363 Wrocław

${ }^{1}$ Katedra Ochrony Roślin, Zakład Fitopatologii i Mikologii

${ }^{2}$ Katedra Szczegółowej Uprawy Roślin

*corresponding author: eup.wroc.pl
} 


\section{Wstęp / Introduction}

Najskuteczniejszą ochroną przed chorobami rozwijającymi się w okresie wschodów ziemniaków jest zaprawianie materiału sadzeniakowego, dlatego nabiera ono dużego znaczenia w uprawie ziemniaka. Wiosenne zaprawianie pozwala na zabezpieczenie bulw w okresie największej szkodliwości chorób powodowanych przez grzyby, ponieważ chore bulwy są głównym źródłem infekcji na wiosnę (Osowski i Bernat 2010). Zaprawione bulwy stanowią także zabezpieczenie przed zimującymi w glebie Rhizoctonia solani czy Streptomyces scabiei, mogącymi w sprzyjających warunkach atakować rozwijające się kiełki i młode rośliny ziemniaka. Ponadto rośliny wyrastające $\mathrm{z}$ zaprawianych sadzeniaków szybciej rosną i są silniejsze. Zdrowy, nieporażony sadzeniak jest bardzo ważny w uprawie ziemniaka, gdyż prowadzi do eliminacji pierwotnego źródła licznych chorób oraz zmniejszenia potencjału infekcyjnego patogenów w środowisku (Kapsa 2006).

Jako element walki biologicznej w ochronie ziemniaka przed patogenami wykorzystywane są takie mikroorganizmy, jak niepatogeniczny izolat Rhizoctonia spp., który chronił rośliny ziemniaka przed infekcją przez $R$. solani (Bandy i Tavantzis 1990), czy grzyb Trichoderma harzianum hamujący rozwój rizoktoniozy pod koniec okresu wegetacji, chociaż najlepszą ochronę ziemniaka przed $R$. solani podczas całego okresu wegetacji stanowiła łączna aplikacja tego grzyba i flutolanilu (Wilson i wsp. 2008). W badaniach Kurzawińskiej i Mazura (2007) biologicznie czynny preparat Polyversum WP także okazał się skuteczny w ograniczaniu wzrostu i rozwoju grzybów patogenicznych dla ziemniaka. Spośród zapraw chemicznych, zastosowanie substancji czynnej pencykuronu oraz karboksyny z tiuramem również skutecznie ograniczało porażenie ziemniaka przez R. solani (Bernat i Osowski 2006).

Celem badań było określenie wpływu zaprawiania sadzeniaków zaprawą chemiczną oraz zaprawami biologicznymi na porażenie bulw potomnych przez $R$. solani i S. scabiei, wielkość wschodów oraz plonowanie ziemniaków.

\section{Materiały i metody / Materials and methods}

Badania polowe przeprowadzono w latach 2011-2013 w Pawłowicach, należących do Uniwersytetu Przyrodniczego we Wrocławiu, metodą split-plot, w czterech powtórzeniach, na glebie brunatnej, kompleksu żytniego bardzo dobrego, klasy IVb. Przedplonem było pszenżyto jare uprawiane współrzędnie $\mathrm{z}$ bobikiem.

Czynniki doświadczenia: I. Zaprawy - 1. obiekt kontrolny (bez zaprawiania), 2. zaprawa chemiczna (Prestige 290 FS), 3. zaprawy biologiczne: FZB 24 WG, Proradix WP, II. Odmiany: Cyprian (wczesna), Finezja (średnio wczesna), Flaming (bardzo wczesna), zróżnicowane pod względem odporności na patogeny (tab. 1). Poletka do sadzenia i zbioru miały wielkość $15 \mathrm{~m}^{2}$ (4 rzędy $\times 0,75 \mathrm{~m}$ szerokości $\times 5 \mathrm{~m}$ długości). Ziemniaki sadzono w drugiej dekadzie kwietnia.

Przed sadzeniem odliczono po 240 bulw każdej odmiany do wysadzenia na poszczególnych obiektach. Zważono
Tabela 1. Odporność odmian na patogeny (COBORU)

Table 1. Resistance of cultivars to pathogens (COBORU)

\begin{tabular}{l|c|c|c}
\hline \multirow{2}{*}{$\begin{array}{c}\text { Odmiana } \\
\text { Cultivar }\end{array}$} & \multicolumn{3}{|c}{ Patogen - Pathogen } \\
\cline { 2 - 4 } & PVY & PLRV & $\begin{array}{c}\text { parch zwykły } \\
\text { ziemniaka } \\
\text { common scab } \\
\text { of potato }\end{array}$ \\
\hline Cyprian & $5-6$ & $5-6$ & 5,5 \\
\hline Finezja & 9 & 7 & 6,5 \\
\hline Flaming & 9 & 7 & 6 \\
\hline
\end{tabular}

PTV - Potato Virus Y

PLRV - Potato Leafroll Virus

je, aby obliczyć dokładną ilość preparatu do zaprawiania. Sadzeniaki zaprawiano tuż przed sadzeniem na mokro: zaprawa chemiczna Prestige 290 FS - $100 \mathrm{ml} / 100 \mathrm{~kg}$ sadzeniaków, zaprawy biologiczne: FZB $24 \mathrm{WG}-250 \mathrm{~g} / \mathrm{ha}$, Proradix WP - $20 \mathrm{~g} / \mathrm{t}$ sadzeniaków. Zaprawa chemiczna Prestige 290 FS jest mieszaniną dwóch substancji czynnych, pencykuronu - fungicydu kontaktowego oraz imidachloprydu - insektycydu systemicznego w postaci koncentratu zawiesinowego. Spośród dwóch zapraw biologicznych - zaprawa FZB 24 WG zawiera szczep bakterii Bacillus subtilis, który kolonizuje górne warstwy gleby i strefy korzeniowej roślin uprawnych, natomiast zaprawa Proradix WP zawiera bakterie Pseudomonas spp., które tworzą kolonie w sferze korzeniowej. Po wschodach na każdym poletku określano procent ubytków roślin i przyczyny braków wschodów (brak sadzeniaka, sadzeniak nie kiełkuje - zgniłe kiełki, sadzeniak zgniły). W latach 2011-2013, po zbiorze bulw, obliczono procent bulw porażonych przez $R$. solani (ospowatość bulw) i $S$. scabiei. Oceniono po 40 niezaprawionych i zaprawionych bulw (Prestige 290 FS, FZB 24 WG, Proradix WP) każdej odmiany, w czterech powtórzeniach (144 próby). W trakcie zbioru ziemniaków pobierano próby bulw, w celu określenia struktury otrzymanego plonu. Po zbiorze zważono plon ogólny bulw z każdego poletka.

Uzyskane wyniki opracowano statystycznie metodą analizy wariancji dla doświadczenia dwuczynnikowego, założonego metodą split-plot. Istotność wpływu badanych czynników określono na podstawie testu $\mathrm{F}$ w analizie wariancji. Różnice graniczne określono przez zastosowanie testu Tukeya przy poziomie ufności $\alpha=0,05$.

\section{Wyniki i dyskusja / Results and discussion}

Rozwój fenologiczny ziemniaka różnił się w czasie trzyletnich badań. Zależał on od użytych zapraw nasiennych, odmian i był modyfikowany przez warunki pogodowe w okresie wegetacji. Po zakończeniu wschodów obserwowano na poletkach nieznaczne ubytki roślin, sięgające 3\%, które były spowodowane brakiem sadzeniaka, gniciem jego kiełków lub gniciem sadzeniaka. Porównując badane zaprawy, istotnie wyższe wschody wystąpiły na obiektach, w których zastosowano zaprawę Prestige 290 FS, niż po zastosowaniu zapraw biologicznych FZB 24 WG i Proradix WP oraz bulw niezaprawionych. Spośród badanych odmian najmniej ubyt- 
ków roślin stwierdzono w przypadku odmiany Flaming (tab. 2). Warunki pogodowe w latach 2011-2013 były zróżnicowane, temperatura przewyższała średnią wieloletnią, a rozkład opadów był bardzo nierównomierny (tab. 3). Największe wschody wystąpiły w 2012 roku i istotnie przewyższały wschody w latach 2011 i 2013 (tab. 2).

Rizoktonioza ziemniaka powodowana przez grzyb $R$. solani oraz parch zwykły ziemniaka powodowany przez bakterie $S$. scabiei i $S$. acidiscabies należą do ważnych gospodarczo chorób w uprawie ziemniaka (Loria i wsp. 2006). W czasie trzyletnich badań procentowy udział bulw porażonych przez $R$. solani zależał od zastosowanych zapraw oraz warunków pogodowych, natomiast nie zależał od zastosowanych odmian. Najliczniej zmiany chorobowe w postaci sklerot $R$. solani na powierzchni bulw wystąpiły w przypadku niezaprawionych ziemniaków (60,4\%). Zastosowanie zaprawy chemicznej Prestige 290 FS istotnie ograniczyło procent bulw $(8,0 \%)$ porażonych przez $R$. solani $\mathrm{w}$ porównaniu do zapraw biologicznych: Proradix WP $(44,0 \%)$ oraz FZB 24 WG (50,2\%) (tab. 4). Zaprawianie bulw jest jedynym ze sposobów wyeliminowania sprawców chorób przenoszonych przez materiał sadzeniakowy, aby w czasie wschodów rośliny nie były narażone na rizoktoniozę ziemniaka i szkodniki glebowe (Osowski 2004; Bernat i Osowski 2006). Znane jest efektywne ograniczanie infekcji $R$. solani po zastosowaniu pencykuronu, substancji czynnej zaprawy Prestige 290 FS, na plantacjach ziemniaka we Francji (Campion i wsp. 2003). Jednak Cwalina-Ambroziak i Trojak (2011) stwierdziły niższą skuteczność grzybobójczą zaprawy Prestige 290 FS i słabszą ochronę ziemniaka przed infekcją przez $R$. solani w przypadku zastosowania środków Dithane M 4575 WG lub Vitavax 2000 FS.

Tabela 2. Przyczyny braku wschodów [\%]

Table 2. The causes of the lack of potato germinations [\%]

\begin{tabular}{|c|c|c|c|c|c|c|}
\hline $\begin{array}{l}\text { Rok } \\
\text { Year }\end{array}$ & $\begin{array}{l}\text { Zaprawa nasienna } \\
\text { Seed treatment }\end{array}$ & $\begin{array}{l}\text { Odmiana } \\
\text { Cultivar }\end{array}$ & $\begin{array}{l}\text { Brak sadzeniaka } \\
\text { Lack of seed } \\
\text { potato }\end{array}$ & $\begin{array}{c}\text { Sadzeniak } \\
\text { nie wschodzi } \\
\text { Seed potato doesn't } \\
\text { rise }\end{array}$ & $\begin{array}{c}\text { Zgniły } \\
\text { sadzeniak } \\
\text { Rotten seed } \\
\text { potato }\end{array}$ & $\begin{array}{l}\text { Suma } \\
\text { Total }\end{array}$ \\
\hline 2011 & - & - & 2,10 & 0,93 & 0,10 & $3,13 \mathrm{a}$ \\
\hline 2012 & - & - & 1,24 & 0,17 & 0,17 & $1,58 \mathrm{~b}$ \\
\hline 2013 & - & - & 2,91 & 0,21 & 0,19 & $3,31 \mathrm{a}$ \\
\hline \multicolumn{3}{|c|}{$\operatorname{NIR}(\alpha=0,05)-\operatorname{LSD}(\alpha=0.05)$} & 0,23 & 0,14 & r.n. & 0,24 \\
\hline- & kontrola - control & - & 2,80 & 0,77 & 0,27 & $3,84 \mathrm{a}$ \\
\hline- & Prestige $290 \mathrm{FS}$ & - & 1,33 & 0,07 & 0,06 & $1,46 \mathrm{c}$ \\
\hline- & FZB $24 \mathrm{WG}$ & - & 2,00 & 0,50 & 0,17 & $2,67 \mathrm{~b}$ \\
\hline- & Proradix WP & - & 2,20 & 0,37 & 0,10 & $2,67 \mathrm{~b}$ \\
\hline \multicolumn{3}{|c|}{$\operatorname{NIR}(\alpha=0,05)-\operatorname{LSD}(\alpha=0.05)$} & 0,18 & 0,19 & 0,09 & 0,21 \\
\hline- & - & Cyprian & 2,47 & 0,93 & 0,17 & $3,57 \mathrm{a}$ \\
\hline- & - & Finezja & 2,00 & 0,23 & 0,33 & $2,56 \mathrm{~b}$ \\
\hline- & - & Flaming & 1,77 & 0,10 & 0,07 & $1,94 \mathrm{c}$ \\
\hline \multicolumn{3}{|c|}{$\operatorname{NIR}(\alpha=0,05)-\operatorname{LSD}(\alpha=0.05)$} & r.n. & 0,28 & r.n. & 0,34 \\
\hline
\end{tabular}

r.n. - różnice nieistotne statystycznie - differences not statistically significant

a, b c c - wartości oznaczone tą samą literą nie różnią się istotnie statystycznie - the differences of values followed by the same letters are not statistically significant

Tabela 3. Średnia temperatura powietrza $\left[{ }^{\circ} \mathrm{C}\right]$ oraz suma opadów $[\mathrm{mm}]$ w okresie wegetacji - Wrocław-Swojec

Table 3. Average of air temperature $\left[{ }^{\circ} \mathrm{C}\right]$ and sum of rainfall $[\mathrm{mm}]$ in the growing period - Wrocław-Swojec

\begin{tabular}{|c|c|c|c|c|c|c|}
\hline Miesiąc - Month & IV & $\mathrm{V}$ & VI & VII & VIII & IX \\
\hline Rok - Year & \multicolumn{6}{|c|}{ temperatura - air temperature $\left[{ }^{\circ} \mathrm{C}\right]$} \\
\hline 2011 & 11,9 & 14,8 & 19,1 & 18,2 & 19,3 & 15,5 \\
\hline 2012 & 9,8 & 15,8 & 17,2 & 20,0 & 19,3 & 14,6 \\
\hline 2013 & 9,2 & 14,6 & 17,7 & 20,5 & 19,0 & 12,8 \\
\hline $1981-2010$ & 8,9 & 14,4 & 17,1 & 19,3 & 18,3 & 13,6 \\
\hline Rok - Year & \multicolumn{6}{|c|}{ opady - rainfall [mm] } \\
\hline 2011 & 27,0 & 49,4 & 95,7 & 170,9 & 78,9 & 30,4 \\
\hline 2012 & 27,6 & 63,7 & 94,7 & 108,0 & 73,2 & 52,6 \\
\hline 2013 & 42,7 & 135,9 & 171,7 & 36,3 & 68,2 & 105,8 \\
\hline $1981-2010$ & 30,5 & 51,3 & 59,5 & 78,9 & 61,7 & 45,3 \\
\hline
\end{tabular}


Największy procent bulw z objawami w postaci sklerot (64,3\%) stwierdzono w 2012 roku, natomiast najmniej bulw porażonych przez $R$. solani było w 2011 roku $(31,1 \%)$ i 2013 roku (26,5\%) (tab. 4). Rozwojowi $R$. solani sprzyjają wysoka wilgotność gleby i niska temperatura powietrza (Lutomirska 2007). Nierównomiernie rozłożone opady w 2012 roku, znacznie przewyższające wielolecie okazały się dogodne do rozwoju $R$. solani (tab. 3). Skleroty R. solani zimują na porażonych bulwach oraz $\mathrm{w}$ glebie $\mathrm{i}$ stanowią źródło infekcji dla zdrowych roślin (Ahvenniemi i wsp. 2005). Skleroty mogą przeżyć w glebie kilka lat, dlatego uprawa ziemniaka $\mathrm{W}$ zmianowaniu może ograniczyć częstotliwość występowania oraz nasilenie objawów chorobowych (Larkin i Honeycutt 2006). Bulwy trzech badanych odmian, ze zbioru $\mathrm{w}$ latach 2011-2013 nie były zróżnicowane pod względem porażenia przez $R$. solani (tab. 4).

Tabela 4. Procent bulw porażonych przez Rhizoctonia solani i Streptomyces scabiei (po zbiorze) w latach 2011-2013

Table 4. Percentage of tubers infected by Rhizoctonia solani and Streptomyces scabiei (after harvest) in 2011-2013

\begin{tabular}{|c|c|c|c|c|}
\hline $\begin{array}{l}\text { Lata } \\
\text { Years }\end{array}$ & $\begin{array}{l}\text { Zaprawa nasienna } \\
\text { Seed treatment }\end{array}$ & $\begin{array}{l}\text { Odmiana } \\
\text { Cultivar }\end{array}$ & $\begin{array}{l}\% \text { bulw porażonych } \\
\text { przez Rhizoctonia solani } \\
\% \text { of infected tubers } \\
\text { by Rhizoctonia solani }\end{array}$ & $\begin{array}{c}\% \text { bulw porażonych } \\
\text { przez Streptomyces scabiei } \\
\% \text { of infected tubers } \\
\text { by Streptomyces scabiei }\end{array}$ \\
\hline 2011 & - & - & $31,1 \mathrm{~b}$ & 7,08 \\
\hline 2012 & - & - & $64,3 \mathrm{a}$ & 6,04 \\
\hline 2013 & - & - & $26,5 \mathrm{c}$ & 8,19 \\
\hline \multicolumn{3}{|c|}{$\operatorname{NIR}(\alpha=0,05)-\operatorname{LSD}(\alpha=0.05)$} & 3,16 & r.n. \\
\hline- & kontrola - control & - & $60,4 \mathrm{a}$ & 12,2 \\
\hline- & Prestige 290 FS & - & $8,0 \mathrm{~d}$ & 6,57 \\
\hline- & FZB 24 WG & - & $50,2 \mathrm{~b}$ & 5,00 \\
\hline- & Proradix WP & - & $44,0 \mathrm{c}$ & 4,63 \\
\hline \multicolumn{3}{|c|}{$\operatorname{NIR}(\alpha=0,05)-\operatorname{LSD}(\alpha=0.05)$} & 5,06 & r.n. \\
\hline- & - & Cyprian & 40,0 & $10,69 \mathrm{ab}$ \\
\hline- & - & Finezja & 41,7 & $4,31 \mathrm{~b}$ \\
\hline- & - & Flaming & 40,3 & $6,32 \mathrm{~b}$ \\
\hline \multicolumn{3}{|c|}{$\operatorname{NIR}(\alpha=0,05)-\operatorname{LSD}(\alpha=0.05)$} & r.n. & 4,8 \\
\hline
\end{tabular}

r.n. - różnice nieistotne statystycznie - differences not statistically significant

a, b, c - wartości oznaczone tą samą literą nie różnią się istotnie statystycznie - the differences of values followed by the same letters are not statistically significant

Tabela 5.Plon bulw ogółem, frakcji handlowej [t/ha] i średnia masa bulwy [g]

Table 5. Total tuber yield, commercial fraction $[\mathrm{t} / \mathrm{ha}]$, and the average tuber mass $[\mathrm{g}]$

\begin{tabular}{|c|c|c|c|c|}
\hline \multirow{2}{*}{$\begin{array}{l}\text { Rok } \\
\text { Year }\end{array}$} & \multirow{2}{*}{$\begin{array}{l}\text { Zaprawa nasienna } \\
\text { Seed treatment }\end{array}$} & \multirow{2}{*}{$\begin{array}{l}\text { Odmiana } \\
\text { Cultivar }\end{array}$} & \multicolumn{2}{|c|}{ Plon bulw - Yield of tuber } \\
\hline & & & ogółem - total & $\begin{array}{l}\text { plon handlowy } \\
\text { marketable yield }\end{array}$ \\
\hline 2011 & - & - & $49,8 \mathrm{a}$ & $36,5 \mathrm{~b}$ \\
\hline 2012 & - & - & $45,8 \mathrm{a}$ & $40,6 \mathrm{a}$ \\
\hline 2013 & - & - & $22,7 \mathrm{~b}$ & $13,7 \mathrm{c}$ \\
\hline \multicolumn{3}{|c|}{$\operatorname{NIR}(\alpha=0,05)-\operatorname{LSD}(\alpha=0.05)$} & 3,46 & 3,12 \\
\hline- & kontrola - control & - & 37,2 & 27,7 \\
\hline- & Prestige 290 FS & - & 39,4 & 29,5 \\
\hline- & FZB $24 \mathrm{WG}$ & - & 40,6 & 32,2 \\
\hline- & Proradix WP & - & 40,4 & 31,6 \\
\hline \multicolumn{3}{|c|}{$\operatorname{NIR}(\alpha=0,05)-\operatorname{LSD}(\alpha=0.05)$} & r.n. & r.n. \\
\hline- & - & Cyprian & $38,4 \mathrm{~b}$ & $30,5 \mathrm{~b}$ \\
\hline- & - & Finezja & $45,5 \mathrm{a}$ & 37,9 a \\
\hline- & - & Flaming & $34,4 \mathrm{c}$ & $22,2 \mathrm{c}$ \\
\hline \multicolumn{3}{|c|}{$\operatorname{NIR}(\alpha=0,05)-\operatorname{LSD}(\alpha=0.05)$} & 2,72 & 2,45 \\
\hline
\end{tabular}

r.n. - różnice nieistotne statystycznie - differences not statistically significant

a, b, c, d - wartości oznaczone tą samą literą nie różnią się istotnie statystycznie - the differences of values followed by the same letters are not statistically significant 
W czasie trzyletnich badań, procentowy udział bulw porażonych przez S. scabiei był niski. Najwięcej bulw $\mathrm{Z}$ objawami parcha stwierdzono na bulwach niezaprawionych (12,2\%). Zastosowanie zaprawy chemicznej oraz zapraw biologicznych (zawierających bakterie Pseudomonas spp. lub B. subtilis) nie wpłynęło różnicująco na procent bulw $\mathrm{z}$ objawami tej choroby (tab. 4). Kraska i Pałys (2008) także nie stwierdzili wpływu ochrony chemicznej na porażenie bulw przez S. scabiei. Al-Mughrabi (2010) wykazał, że szczep bakterii Pseudomonas fluorescens spowodował obniżenie porażenia bulw ziemniaka przez S. scabiei o ponad $20 \%$ w porównaniu do kontroli. Meng i wsp. (2012) uważają nawet, że szczepy bakterii Bacillus spp., w tym Bacillus subtilis (użyte w badanej zaprawie FZB 24 WG) mogą być wykorzystywane w biologicznej walce $\mathrm{z}$ parchem ziemniaka. Biorąc pod uwagę badane odmiany, największy procent bulw porażonych przez $S$. scabiei stwierdzono u odmiany Cyprian i był on istotnie wyższy niż bulw odmiany Finezja (tab. 4). Zróżnicowane porażenie odmian ziemniaków przez S. scabiei stwierdził także Lenc (2006). W latach 2011-2013 uszkodzenie bulw przez S. scabiei kształtowało się na tym samym poziomie (tab. 4).

Plon frakcji handlowej był bardzo zróżnicowany i zależał od warunków pogodowych oraz odmian. W czasie trzyletnich badań istotnie wyższe plony bulw wystąpiły w $2012 \mathrm{roku}(40,6 \mathrm{t} / \mathrm{ha})$ i $2011 \mathrm{roku}(36,5 \mathrm{t} / \mathrm{ha})$, natomiast najniższe w 2013 roku (13,7 t/ha), kiedy opady w maju i czerwcu kilkakrotnie przewyższały opady $\mathrm{z}$ wielolecia (tab. 3, 5). Spośród badanych odmian najwyższe plony uzyskano z odmiany Finezja i Cyprian. Nie stwierdzono natomiast wpływu zaprawy chemicznej i zapraw biologicznych na wielkość plonu bulw (tab. 5). Jak podaje Osowski (2004) zastosowanie zapraw nie zawsze wpływa na wzrost plonu ogólnego, ale polepsza jego jakość. Natomiast według Platta i MacLeana (1997) zaprawianie wpływa korzystnie na wielkość bulw i wysokość plonu handlowego.

\section{Wnioski / Conclusions}

1. Zastosowanie zaprawy chemicznej Prestige 290 FS wpłynęło istotnie na wyższe wschody oraz ograniczyło procent bulw porażonych przez $R$. solani w porównaniu do zapraw biologicznych i bulw niezaprawionych.

2. Procentowy udział bulw porażonych przez $R$. solani zależał od zastosowanych zapraw oraz warunków pogodowych, natomiast nie zależał od uprawianych odmian.

3. Zastosowanie zaprawy chemicznej oraz zapraw biologicznych nie wpłynęło różnicująco na procentowy udział bulw porażonych przez $S$. scabiei, co mogło być spowodowane bardzo niskim porażeniem przez tego patogena.

4. Procentowy udział bulw porażonych przez S. scabiei odmiany Cyprian był istotnie wyższy niż bulw odmiany Finezja.

5. Zastosowanie zaprawy chemicznej i zapraw biologicznych nie wpłynęło istotnie na wielkość plonu bulw ziemniaka.

6. Najwyższe plony uzyskano z odmiany Finezja.

Badania wykonane w ramach projektu 7252/B/P01/ 2011/40 „Stosowanie biologicznych zapraw do ochrony ziemniaka, jako alternatywnej metody ochrony roślin i indukowania reakcji obronnych w roślinie", finansowanego przez Narodowe Centrum Badań.

\section{Literatura / References}

Ahvenniemi P.M., Lehtonen M.J., Wilson P.S., Vilkonen J.P.T. 2005. Influence of farming system and black scurf infestation level of seed tubers on stem canker and black scurf (Rhizoctonia solani): of potato. Abstracts of 16th Triennial Conference EAPR. Bilbao, 17-22.07.2005: 335-338.

Al-Mughrabi K.I. 2010. Biological control of Fusarium dry rot and other potato tuber diseases using Pseudomonas fluorescens and Enterobacter cloacae. Biological Control 53 (3): 280-284.

Bandy B.P., Tavantzis S.M. 1990. Effect of hypovirulent Rhizoctonia solani on Rhizoctonia disease, growth and development of potato plants. American Journal of Potato Research 67 (3): 189-199.

Bernat E., Osowski J. 2006. Wpływ różnych terminów zaprawiania na tempo wschodów i zdrowotność ziemniaka. [The influence of different seed dressing date on the emergence rate and healthiness of potato]. Progress in Plant Protection/Postępy w Ochronie Roślin 46 (1) 2: 401-407.

Campion C., Chatot C., Perraton B., Andrivon D. 2003. Anastomosis groups, pathogenicity and sensitivity to fungicides of Rhizoctonia solani isolates collected on potato crops in France. European Journal of Plant Pathology 109 (9): 983-992.

Cwalina-Ambroziak B., Trojak A. 2011. Wpływ zaprawiania sadzeniaków na nasilenie ospowatości i antraknozy bulw. [The effect of dressing of seeds tubers of potato on the intensity of rhizoctoniosis and antracnose]. Progress in Plant Protection/Postępy w Ochronie Roślin 51 (2): 638-643.

Kapsa J. 2006. Ochrona ziemniaka bezpieczniejsza dla środowiska. Agrotechnika 5/2006: 32-34.

Kraska P., Pałys E. 2008. Wpływ systemów uprawy roli oraz poziomów nawożenia i ochrony na porażenie bulw ziemniaka przez Streptomyces scabies i Rhizoctonia solani. [The influence of tillage systems and fertilization and plant protection levels on potato tuber infestation by Streptomyces scabies and Rhizoctonia solani]. Progress in Plant Protection/Postępy w Ochronie Roślin 48 (1): 204-207.

Kurzawińska H., Mazur S. 2007. Przydatność Pythium oligandrum w ochronie ziemniaka przed niektórymi chorobami. [Usefulness of Pythium oligandrum in the protection of potato against some diseases]. Progress in Plant Protection/Postępy w Ochronie Roślin 47 (4): 185-188.

Larkin R.P., Honeycutt C.W. 2006. Effects of different 3-year cropping systems on soil microbial communities and Rhizoctonia diseases of potato. Phytopathology 96 (1): 68-79. 
Lenc L. 2006. Rhizoctonia solani and Streptomyces scabies on sprouts and tubers of potato grown in organic and integrated systems, and fungal communities in the soil habitat. Phytopathologia Polonica 42: 13-28.

Loria R., Kers J., Joshi M. 2006. Evolution of plant pathogenicity in Streptomyces. Annual Review of Phytopathology 44: 469-487.

Lutomirska B. 2007. Wpływ odmiany i czynników meteorologicznych okresu wegetacji na ospowatość bulw ziemniaka. [The influence of cultivar and meteorological factors during vegetation season on black scurf of potato tubers]. Progress in Plant Protection/Postępy w Ochronie Roślin 47 (2): 173-177.

Meng Q.X., Yin J.F., Rosenzweig N., Douches D., Hao J.J. 2012. Culture-based assessment of microbial communities in soil suppressive to potato common scab. Plant Disease 96: 712-717.

Osowski J. 2004. Wpływ wiosennego zaprawiania bulw ziemniaka na występowanie rizoktoniozy oraz wielkość i jakość plonu. [Influence of seed potato spring dressing on occurrence of black scurf and yield quantity and quality]. Biuletyn Instytutu Hodowli i Aklimatyzacji Roślin 232: 295-300.

Osowski J., Bernat E. 2010. Wpływ terminów zaprawiania i krojenia bulw na tempo wschodów i porażenie roślin rizoktoniozą ziemniaka. [The effect of date of seed dressing and cutting of tuber on emergence rate and infection of plant by Rhizoctonia canker]. Progress in Plant Protection/Postępy w Ochronie Roślin 50 (2): 689-694.

Platt H.W., MacLean V.M. 1997. Efficacy of chemical control products for control of soil-borne potato diseases caused by soil-borne fungal pathogens in 1995. Tests of agrochemicals and cultivars. Annals of Applied Biology 130: 16-17.

Wilson P.S., Ahvenniemi P.M., Lehtonen M.J., Kukkonen M., Rita H., Valkonen J.P.T. 2008. Biological and chemical control and their combined use to control different stages of the Rhizoctonia disease complex on potato through the growing season. Annals of Applied Biology 153 (3): 307-320. 